\title{
Application of oak tasar waste silk and viscose blended fabrics for apparel purpose
}

\section{Pooja and Sandeep Bains}

Received: 26.07.2018; Accepted: 31.05.2019

See end of the paper for authors' affiliations Pooja

Department of Apparel and Textile Science, Punjab Agricultural University , Ludhiana (Punjab) India Email : poojakaunda10007@ gmail.com
ABSTRACT : Application of oak tasar waste silk and viscose blended fabrics for apparel purposehas been studied. Oak tasar silk waste was blended with viscose fibre in three different ratios, viz., 60s: 40v, 50s: 50v and 40s: 60v on worsted spinning system. Knitted fabric samples were then prepared on circular knitting machine. Properties of resultant yarn and knitted fabric were evaluated. The developed blended fabrics were subjectively analyzed for their end use applications for women's wear, men's wear, children wear and home textiles. It was found that, in case of womens apparel, the respondents preferred fabric samples $S_{1}$ and $S_{2}$ for making shrugs and fabric samples $\mathrm{S}_{3}$ and $\mathrm{S}_{4}$ were preferred for making ponchos. When talking about mens apparel, fabric sample $\mathrm{S}_{1}, \mathrm{~S}_{2}, \mathrm{~S}_{3}$ and $\mathrm{S}_{4}$ followed same trend of rating. First rating was given to mufflers. In case of children wear, caps were mostly preferred by respondents for fabric $S_{1}, S_{2}$ and $S_{3}$ whereas sweater was mostly preferred for fabric sample $S_{4}$. As far as the use of developed blended fabrics for home textiles was concerned, first rank for fabrics $S_{1}, S_{2}$ and $S_{3}$ was obtained by bed sheets and pillow covers and fabric $S_{4}$ obtained first rank for making quilt covers.

KEY WORDS: Oak tasar waste, Ranking, End use, Blended fabrics

- HOW TO CITE THIS PAPER : Pooja and Bains, Sandeep (2019). Application of oak tasar waste silk and viscose blended fabrics for apparel purpose. Asian J. Home Sci., 14 (1) : 247-250, DOI: 10.15740/ HAS/AJHS/14.1/247-250. Copyright@ 2019: Hind Agri-Horticultural Society. 